Running head: Divorce and the multidimensionality of men and women's mental health

\title{
Divorce and the multidimensionality of men and women's mental health: The role of social-relational and socio-economic conditions
}

\author{
Sara Symoens ${ }^{a}$, Sarah Van de Velde ${ }^{a}$, Elien Colman ${ }^{a}$, and Piet Bracke ${ }^{a}$ \\ a Department of Sociology, Ghent University, Ghent, Belgium \\ Corresponding author.
}

\author{
Sara Symoens \\ Ghent University, Department of Sociology \\ Korte Meer 5 \\ 9000 Ghent (BE) \\ Sara.symoens@ugent.be \\ Tel: +329/264 8455 \\ Fax: $+329 / 2646975$ \\ Sarah Van de Velde \\ Ghent University, Department of Sociology \\ Korte Meer 5 \\ 9000 Ghent (BE) \\ Elien Colman \\ Ghent University, Department of Sociology \\ Korte Meer 5 \\ 9000 Ghent (BE) \\ Piet Bracke \\ Ghent University, Department of Sociology \\ Korte Meer 5 \\ 9000 Ghent $(\mathrm{BE})$
}

Article published in Journal of Applied Research in Quality of Life, DOI 10.1007/s11482-013-9239-5 


\title{
Divorce and the multidimensionality of men and women's mental health: The role of social-relational and socio-economic conditions
}

\begin{abstract}
Research consistently reveals that the divorced generally face more mental health problems than the married. Less attention however has been paid to positive mental health indicators. Insight in these however may help policy makers and care providers to see both the broader picture and stimulate active coping. Using data from the European Social Survey (2006-2007), differences in both feelings of depression, and in feelings of self-esteem, autonomy, and competence between the married $(\mathrm{N}=14,072)$ and divorced $(\mathrm{N}=4,304)$ are estimated for women and men separately. Drawing on stress and coping theories, we map how specific social-relational and socio-economic conditions relate. Analyses reveal that divorce is related not only to more feelings of depression, but also to lower levels of self-esteem and competence. Difference scores in mental health based on marital status are also found to differ significantly between men and women for competence, with the difference being more pronounced in men. Additionally, social-relational and socio-economic conditions explain much of the gap in depression scores - and to a lesser extent, in self-esteem and competence scores - between the married and divorced. Finally, some interesting gender differences were found in how social-relational and socio-economic conditions relate to mental health when divorced, with women especially seeming to benefit from advantageous socio-economic conditions.
\end{abstract}

Keywords divorce; gender; mental health; stress; wellbeing 
Divorce and the multidimensionality of men and women's mental health.

\section{Divorce and the multidimensionality of men and women's mental health: The role of social-relational and socio-economic factors}

\section{Introduction}

Despite the increased presence of divorce and the growing social visibility of new family structures that contribute to the normalisation of divorce (Ishida 2003), a higher prevalence of mental health problems among the ever divorced compared to the continuously married remains a consistent finding in the social epidemiology of mental health (Amato 2000; Bracke 1998; Kalmijn 2010; Kitson 1992; Lucas 2005; Strohschein et al. 2005).

This heightened susceptibility to mental health problems has been attributed mainly to the different socialrelational and socio-economic changes that divorcees face after divorce (Amato 2000; Wang and Amato 2000). How this susceptibility differs between men and women is less clear. Some researchers have found support for the idea that women suffer more from divorce than men (Asseltine and Kessler 1993; Horwitz et al. 1996; Kalmijn and Monden 2006; Simon and Marcussen 1999), while others have argued that men are worse off when divorced (Lucas 2005; Marks 1996; Peters and Liefbroer 1997).

Most research on the mental health of divorcees focuses solely on negative outcomes, such as depression and anxiety (e.g., Asseltine and Kessler 1993; Booth and Amato 1991; Bracke 1998; Cohen et al. 2007; Strohshein et al. 2005), or on negative health related behaviour, such as problem drinking (e.g., Lee et al. 2005; Liang and Chikritzhs 2012; Matzger et al. 2004; Power et al. 1999). However, it remains unclear whether divorce can also lead to positive mental health outcomes, as it might in cases where, for example, the prior spousal role was experienced as highly stressful. Current studies that consider both indicators of distress and positive mental health are limited in number or have several shortcomings: they are based on small or nonrepresentative samples (e.g., Chung et al. 2002; Wang and Amato 2000), focus on only one indicator of positive mental health (e.g., Amato and Hohmann-Marriott 2007; Ross 1991), or stems from the eighties (e.g., Barron 1987; Etaugh and Foresman 1983). Furthermore, it remains unclear how these positive indicators of wellbeing relate to gender.

The aim of the current study is threefold. First, we intend to investigate whether the mental health of the married and the divorced differs, to what extent, and how gender interferes in this relationship. By considering both positive and negative indicators of mental health, we acknowledge mental health as being more than solely the absence of problems (Ryff 1989). In line with this idea, we use a contextual approach that does not define 
divorce as inherently stressful (Wheaton 1990). Second, in line with Bierman, Fazio and Milkie (2006) we examine how conditions of one's daily socio-economic and social-relational environment can explain differences in mental health. Finally, we investigate how these conditions are differently associated with the mental health of divorced men versus women. We use the European Social Survey (2006-2007), a recent and large populationrepresentative dataset.

\section{Background}

\section{Divorce and Mental Health}

The heightened susceptibility of divorcees to mental health problems is often explained by Stress and Coping Theories (Pearlin et al. 1981; Pearlin 1989), such as the Stress-divorce-adjustment Perspective (Amato, 2000) On one hand, these hypothesise that divorce is a stressful experience that creates more stressors, thus provoking mental health problems and tempering life satisfaction and happiness in general (Veenhoven 1985). On the other hand, they also assume that divorcees are more vulnerable to mental health problems as they generally have fewer resources for coping with stress than the married (Amato 2000; Bracke 1993; Gerstel et al. 1985; Turner et al. 1995; Wang and Amato 2000; Wheaton 1983). Indeed, divorcees are often confronted with stressful socioeconomic changes, such as economic hardship and poverty due to declines in relative household income, a change in a job situation, receiving sole custody of children, and/or complex new family arrangements (e.g., Bracke 1998; Fokkema 2001; Kitson and Morgan 1990). Similarly, the lack of a partner, a move to another neighbourhood, and reductions in social networks with family and friends after divorce decrease the amount of potential social support, just when high-quality support is needed most (e.g., Kalmijn and Broese van Groenou 2005; Kitson and Morgan, 1990; Terhell et al, 2004). For parents, especially fathers, reduced contact with children can be added to the list (Kalmijn and de Graaf 2000). In contrast, firm social networks, a job, a new partner, a high educational degree, and sufficient income can protect divorcees from getting too distressed by maximising support and lowering financial worries (Bracke et al. 2010; Fokkema 2001; Greeff and Van Der Merwe 2004; Kalmijn and Broese van Groenou 2005; Terhell et al. 2004) and by increasing one's sense of mastery and control (Ross 1991). Although selection effects in the association between marriage and mental health cannot be overlooked seen the positive effect of happiness on marriage chances (Veenhoven 1989) and the fact that those in poor mental health are relatively more at risk for relationship tensions and dissolution (Bulloch et al. 2009; Veenhoven 1985), longitudinal studies conclude that most of the association can be explained by the stressful impact divorce has (Johnson and Wu 2002; Joung et al. 1998; Menaghan 1985). 
Divorce and the multidimensionality of men and women's mental health.

\section{The Multidimensional Aspect of Mental Health}

Traditionally, research on the subjective wellbeing of individuals focusses on indicators of distress, such as depression and anxiety, or on hedonic indicators, such as general happiness and life satisfaction. More recently however, eudamonic indicators of positive functioning have been incorporated as well, such as measures for feelings of self-esteem, mastery, and competence (Bierman et al. 2006; Huppert 2006; Keyes 2005; Ryan and Deci 2001; Ryff 1989; Ryff and Singer 1998), also in research on child well-being (e.g. Lippman, Moore and McIntosh 2011). The finding that positive and negative affects only moderately correlate (-.50), suggests that both are simultaneously related but distinct (Bradburn 1969; Huppert and Whittington 2003; Payton 2009), and that subjective wellbeing is more than the absence of mental problems or psychiatric complaints (Horwitz 2002; Keyes et al. 2002). An important criticism of the classical social stress model is that it focusses only on 'stress' or mental ill health. The fact that a number of studies also report increases in positive mental health after lifeevents that are considered 'stressful', such as increased levels of self-worth or personal control, reinforces this criticism (e.g., Marks 1996; Wheaton 1990). In general, research on positive wellbeing is, however, still scarce, especially research that focusses on gender differences in comparing the mental health of the married and the divorced.

\section{Gender and Divorce}

Why bother about gender differences? Though divorce is usually a stressful experience for both women and men, most researchers conclude that women suffer more (Asseltine and Kessler 1993; Kalmijn and Monden 2006; Simon and Marcussen 1999). The explanations given are that they often see their relative household income reduced as men are still the main providers for families today, that they most often receive full custody of the children, and that they have overall fewer chances to meet a new partner than men, in part because of the financial strains and time pressures resulting from the above (Doherty et al. 1989; Fokkema 2001; Horwitz et al. 1996; Marks and Lambert 1998; Turner et al. 1995; Wang and Amato 2000). In contrast, others argue that divorced men have a more pronounced disadvantage with regard to mental health, because exiting and entering marriage entails a different balance of rewards and costs for women and men. On the one hand, married men have better socio-economic prospects: they are less likely to be unemployed than single and divorced men and more likely to be promoted because of better performance (Kalmijn and Luijkx 2005; Korenman and Neumark 1991). On the other hand, the breakdown of a marriage removes the social support of a spouse, from which men especially benefit; and it removes their main kinkeeper, often leaving them isolated after divorce (Gerstel et al. 1985; Kalmijn 2007). Thus, while women especially would profit from practical and financial aid after divorce, 
we can expect good social-relational conditions to be more valuable for divorced men (cf. Gerstel et al. 1985). According to others, however, neither women nor men necessarily experience more stress than the other; rather, they express it differently, with women internalising stress, resulting in psychosocial problems, and with men more often externalising stress, leading to problem behaviour and substance use (Aneshensel et al. 1991; Bracke 1993; Horwitz et al. 1996; Simon 2002; Strohschein et al. 2005).

Moreover, gender theories posit that women are more sensitive to relationships than men, and that their identity is mainly formed by their social environment and how well they are capable of maintaining good relationships (e.g., Rosenthal 1985). Thus, experiencing a divorce and the conflicts that accompany it might lower their self-esteem and increase their chance for mood and anxiety disorders. Divorced men, in contrast, can be expected to have rather lower levels of control and autonomy than the married, because after divorce they suddenly face a wide array of new (household) tasks (Ross 1991), and because divorce is often initiated by their wife (Courtenay 2000). Therefore, it is necessary to use multiple indicators of mental health to understand how the divorced and the married generally differ in subjective wellbeing and to apprehend what role gender plays in this.

\section{Hypotheses}

H1: As divorce is considered a major stressor, we expect the married and the divorced to differ most on feelings of distress, with the latter feeling more depressed, and as an important source of esteem (a partner) disappears, we expect the divorced to have less self-esteem than the married (H1a). Differences in autonomy and competence are expected to be smaller or even to favour the divorced, as a divorce can be seen as a liberation as well (H1b), though it may also be experienced as an upset of one's life, leading to fewer feelings of autonomy and competence (H1c).

H2: Relying on gender theories, we hypothesise that divorced women especially will feel more depressed and report lower self-esteem than their married counterparts (H2a); we expect this to be true for men with regard to feelings of autonomy and competence $(\mathrm{H} 2 \mathrm{~b})$.

H3: In line with prior research, we expect the divorced to more often have a disadvantaged socio-economic position and a less supportive social relational life than the married (H3a). We hypothesise that these disadvantages account, to a large extent, for mental health differences between the married and the divorced (H3b).

H4: Finally, we expect advantageous socio-economic conditions to benefit divorced women especially (H4a), while a good social-relational environment might be more effective for the wellbeing of divorced men (H4b). 


\section{Methods}

\section{Data: The European Social Survey 2006-2007 (ESS3)}

The ESS3 is a biennial survey covering more than 25 European countries in 2006 and 2007 (www.europeansocialsurvey.com; Jowell 2007). This dataset includes a comprehensive module on mental health, incorporating both negative and positive dimensions. For each country, the ESS sample was designed following a strict, randomised probability procedure, and data was gathered by means of standardised face-toface interviews. ESS information is representative for the general population aged 15 and older living in private households, irrespective of their language, citizenship, and nationality. Our analyses are restricted to respondents aged 25 to 60 who are or who have ever been married. We excluded widowed respondents as well as legally separated and cohabiting respondents. These latter were excluded because of cross-national ambiguity about the definition of cohabitation. In addition, we did not consider Latvia and Romania since the design weights for these countries were missing. The unweighted sample consists of 18,376 respondents $(14,072$ still in their first marriage; 4,304 ever-divorced).

\section{Dependent Variables}

Mental health was measured by four dimensions: feelings of depression as a negative indicator, and feelings of autonomy, self-esteem, and competence as positive indicators.

Feelings of depression were measured using an 8-item version of the Center for Epidemiologic StudiesDepression Scale (CES-D 8). The CES-D 8 is constructed to identify populations at risk for developing depressive disorders (Radloff, 1977); it should not be used as a clinical diagnostic tool by itself. Respondents are asked to indicate how often in the week before the survey they felt or behaved in a certain way (felt depressed, felt that everything was an effort, slept badly, felt lonely, felt sad, could not get going, enjoyed life, or felt happy). Response categories range from 1 (none or almost none of the time) to 4 (all or almost or all of the time). Scale scores are assessed using nonweighted, summated rating and range from 8 to 32, with higher scores indicating a greater frequency and severity of depressive complaints. If four or fewer items are missing, mean substitution is applied. Reliability and validity of the inventory are confirmed across gender and countries (Van de Velde et al. 2010).

Self-esteem refers to an individual's feelings of moral value or worth, or to the extent to which people hold themselves in high or low regard (Seff et al. 1992). It was measured by two items: 'In general, I feel very positive about myself', adopted from the self-acceptance scale (reversed scores; Ryff and Singer 1998), and 'At 
times I feel as if I am a failure', adopted from the Rosenberg (1965) self-esteem scale. Summated answers range from 2 (low levels of self-esteem) to 10 (high level of self-esteem). The two items are correlated at the level of R $=0.313$ and show good reliability $($ Spearman-Brown $=0.477)$.

Competence refers to an individual's sense of effectiveness, mastery, or self-efficacy in dealing with the environment, that is, the ability or the skill one has to accomplish tasks (Seff et al. 1992). Competence was measured by two items: 'In my daily life, I get very little chance to show how capable I am' and 'Most days I feel a sense of accomplishment from what I do' (reversed scores). Both items were adopted from the Ryan and Deci (2001) competence scale. Scores vary from 2 to 10, with higher scores indicating more feelings of competence. The correlation between the two items is positive $(R=0.209)$ with a moderate reliability $($ Spearman-Brown $=0.345)$.

Similarly, autonomy refers to feelings of achievement and control, with the absence of physical barriers and power relations (McBride et al. 2005). It was measured by the item 'I feel free to decide how to live my life', adopted from Ryan and Deci's (2001) autonomy scale, with a range of 1 (agree strongly) to 5 (disagree strongly). Scores were reversed.

\section{Independent Variables}

Divorced. We compared respondents who are currently married and have never been divorced before (score 0; referred to as 'married' in the upcoming text) to those who have gone through a divorce, regardless of current partnership status (score 1; referred to as 'ever-divorced'). Hence, this last category also includes divorced respondents who are currently in a new marriage. As prior research of Bierman et al (2006) showed that the continuously married report less distress, also compared to the remarried, comparing the never divorced to the ever divorced as such, makes sense. Moreover, as repartnered and remarried divorcees are initially better adjusted to their divorce and suffer less from mental health problems than the single divorcees (Aseltine and Kessler 1993; Booth and Amato 1991; Kitson and Holmes 1992), excluding them from the divorce category would thus lead to biased results for this category, because then only the worst cases would be included: those less likely to adjust successfully to their divorced status. We also include gender $(0=$ male, $1=$ female $)$ and age .

Social-relational factors. We included the dichotomous variables 'living together with a steady lifepartner, regardless of current marital status', 'having children in the household', and 'having someone to discuss intimate problems with' $(0=$ no, $1=$ yes $)$. A measure of social participation - how often the respondent meets with friends, relatives, or colleagues - was added and measured by a 7-point Likert scale ranging from 1 (never) to 7 (every day). We also added an item of local integration - how close the respondent feels to people in the 
local area - measured by a 5-point Likert scale, with responses ranging from 1 (disagree strongly) to 5 (agree strongly).

Socio-economic factors. The socio-economic position of a respondent was measured by employment status, educational level, and household income. Employment status was coded as either in paid employment (score 1) or not (score 0 ). We measured the educational level of the respondents by the total number of years in full-time education. Respondents who reported having completed more than 30 years of full-time education were capped off at that number $(N=26)$. The income position of respondents was assessed by relative equivalent household income, using the Modified OECD Equivalence Scale (OECD 2005). To account for the high number of item nonresponses, relative equivalent income was coded into five categories, with one category representing respondents with missing data on income. The other categories represented people living in relative poverty (< $50 \%$ of the median equivalent income); a low-income group (50\%-79\% of the median equivalent income); people with an income around the national average ( $80 \%-119 \%$ of the median equivalent income), and people with relatively high incomes ( $\geq 120 \%$ of the median equivalent income; reference category).

\section{Statistical Procedure}

First, differences in the dependent and independent variables between the continuously married and the everdivorced, as well as gender differences, are examined. These results are reported in Table 1. Significant differences in percentages and means are estimated using one-way ANOVA for continuous variables and Chisquare tests for categorical variables. Second, for each dimension of mental health (depression, self-esteem, competence, and autonomy), two models are assessed using the maximum log-likelihood method in a hierarchical linear model (HLM). The first model includes being divorced and gender, along with their interaction term. The second model examines the extent to which the social-relational and socio-economic factors are related with marital differences in negative and positive mental health. All models are adjusted for age. Results are presented in Table 2. Additional interaction terms of the independent variables with divorce are calculated, but only significant results are reported in the text. Finally, the models are replicated only for the divorced population, in which significant interactions of the social-relational and socio-economic conditions with gender are calculated. These results are discussed in the text as well. A multilevel approach was employed because we work with data of individuals grouped into countries. All results were weighted with design weights, correcting for slightly different probabilities of selection. 
Divorce and the multidimensionality of men and women's mental health.

\section{Results}

\section{Descriptive Results}

Descriptive results (Table 1) show that divorced respondents suffer more from depressive complaints and report lower levels of self-esteem, confirming hypothesis 1a. The divorced also report lower levels of competence, though no difference was found for feelings of autonomy, justifying the rejection of hypothesis $1 \mathrm{~b}$ in full and hypothesis $1 \mathrm{c}$ in part. Mental health disparities were most pronounced in terms of feelings of depression. Concerning gender, we note that women report more complaints of depression than men and score lower on all three positive indicators of mental health. The largest mean difference between men and women is reported for self-esteem; the smallest is reported for autonomy.

[Table 1 about here]

The data also indicate that divorcees are -overall- in a more vulnerable social-relational position than the married. Apart from the fact that thy less often cohabit with a partner, they are also less likely than the married to have children living in the household, and do not have a friend to discuss intimate matters with as often as the married do. Divorcees also feel less integrated into their local environment. However, they do meet equally often with friends, relatives, or colleagues. Concerning their socio-economic position, the divorced are more likely to be in paid employment and to have a higher educational degree than married respondents. Unfortunately, this does not translate into a better financial situation, as they report significantly lower income levels than married respondents.

Gender differences in the socio-economic position are more pronounced, with men being more often engaged in paid employment, having completed more years of full-time education, and enjoying a higher income than women. On the other hand, women are more likely to have a confidant or confidante and to feel slightly more integrated in the local community. Nevertheless, women engage somewhat less often in social activities than men. This may be because women also more often bear the responsibility for childcare.

\section{Results of the Multilevel Analysis}

Divorce and gender. The top section of Table 2 gives an overview of the results of our first multilevel model including differences in mental health by marital status, gender, and their interaction term. A separate analysis without the interaction term was also conducted. However, coefficients of the main effects did not differ substantially and are therefore not discussed here. Results confirm that those who have been divorced suffer 
more from mental health problems than those who remain married: They report more depressive feelings and lower levels of self-esteem and competence. Divorce thus seems to be detrimental for both negative and positive mental health dimensions, with the exception of sense of autonomy on which the ever-divorced and the continuously married report equal levels.

Further, women report a lower mental health status than men on all dimensions, irrespective of their marital status. Contrary to our expectations, women and men do not seem to differ notably in how they respond to divorce, as difference scores between the married and the divorced with regard to depression and self-esteem are similar for both. However, while men report in general more feelings of competence than women, among the divorced this is not the case: equal levels of competence are reported between men and women. Therefore, our findings do not confirm hypothesis $2 \mathrm{a}$ and confirm hypothesis $2 \mathrm{~b}$ in part.

The association of socio-economic and social-relational factors with divorce. Because the divorced, in general, face more stressors and have somewhat fewer social-relational and socio-economic resources to rely upon (cf. Table 1), it is likely that they will score worse on mental health. But do these factors bridge the gap? The results of our second model, shown in the lower half of Table 2, show that a substantial part of mental health disparities between the married and the divorced is explained by differences in their social-relational and socioeconomic position. Although the divorced still report more depressive complaints than the married, this contrast is reduced by more than half. Additionally, adjusting for these factors decreases differences in feelings of competence by half, while the differences become insignificant for feelings of self-esteem. Therefore hypothesis $3 \mathrm{~b}$ is confirmed. The level of autonomy remains unrelated to marital status.

Many of the social-relational and socio-economic factors are related to mental health problems, irrespective of respondents' marital status. A better socio-economic position in terms of employment, education, and income is associated with lower levels of depression and higher levels of self-esteem and competence. Employed respondents and those not living in poverty also report more feelings of autonomy.

Results also indicate that having children is related to neither negative nor positive mental health, though respondents with children at home do report somewhat lower levels of autonomy. Living with a partner, irrespective of one's marital status, is negatively associated with feelings of depression and positively with feelings of competence. However, those living with a partner also report fewer feelings of self-esteem and autonomy. Finally, respondents who meet more often with friends, family, and colleagues, who have a confidant or confidante, and who report being well integrated into their local community also tend to be generally in better mental health. 
Divorce and the multidimensionality of men and women's mental health.

[Table 2 about here]

In addition, interaction terms of these social risk factors with marital status (table not shown) indicate that being in paid employment is related to better mental health, especially for the divorced. More than the married, employed divorcees report lower levels of depression, and higher levels of self-esteem, competence, and autonomy. The benefits of having a confidant and of regular social contact in terms of depressive feelings are also more pronounced in the divorced than in the continuously married population; and feelings of autonomy are significantly lower among divorced living in poverty than they are among the married who live in poverty.

Gender differences in the association of socio-economic and social-relational factors with divorce. A replication of our statistical model on the population of the ever divorced only reveals some interesting gender patterns (results not shown). Although, overall, social-relational factors seem to relate similarly to the mental health of both men and women, good socio-economic conditions seem to benefit women especially. In line with general studies on the effect of education, our results show that schooling is an important resource, particularly for women's mental health: women who have been divorced benefit more from higher education in terms of their sense of autonomy and their feelings of depression. Regarding feelings of competence, employment is also more strongly associated with better mental health among women than men. Additionally, a strong social network of friends and family leads women to suffer less from depressive feelings than their male counterparts. However, men who have experienced a divorce express more feelings of autonomy when well integrated into their local neighbourhood than divorced women do. So while hypothesis $4 \mathrm{a}$ can be confirmed, support for hypothesis $4 \mathrm{~b}$ is weaker.

\section{Conclusion and Discussion}

This study focused on assessing differences in mental health between continuously married and ever-divorced men and women, and on the extent to which socio-economic and social-relational factors relate to mental health. Currently, most studies on divorce and divorce adjustment have relied on rather small, local, or non-random samples. In contrast, the ESS3 is a highly qualified international dataset, representing the general population. In addition, it is perfectly suited to the purpose of this study because of its innovation in assessing personal and social wellbeing by using both negative and positive indicators (Huppert 2006). 
Feelings of depression was added as an indicator of mental health complaints, and autonomy, competence, and self-esteem as indicators of positive functioning. Adding the latter allowed to deviate from the dominant discourse that sees life changes as negative events that people passively undergo (Thoits 1994) in favour of an active discourse that focusses on possibilities rather than risks. Consequently, we mainly focused on socio-economic and social-relational conditions that are 'manageable,' rather than on internal and stable characteristics. This is also important for divorce counsellors, family practitioners, and mental health professionals (a) because the multidimensional aspect of mental health underscores that wellbeing is more than the absence of distress, meaning that there is more to achieve than simply getting clients to a point where they are 'not feeling depressed', and (b) because improving concrete life conditions (social integration, work, education, etc.) might also prove valuable in overcoming distress and helping people to cope with major life changes such as divorce. Studies on rumination, for example, found that active coping (or 'doing') is often a more efficient means of overcoming depression than focussing on what happened, why it happened, and how one feels about that (i.e., 'thinking'; Nolen-Hoeksema and Jackson 2001).

\section{Important Findings}

First, results reveal that ever divorced persons report overall weaker mental health than the continuously married do: they report more symptoms of depression and have lower levels of self-esteem and competence. Scores in feelings of autonomy did not differ by marital status.

Second, the idea that women strive for relatedness and men for individualism (Bracke 1998, 2000; Courtenay 2000; McBride et al. 2005) assumes that, in general, women prioritise investment in interpersonal relationships while men focus more on being active, successful, and autonomous. This assumption led us to hypothesise that divorced women will suffer more from an increase in depression and from lower self-esteem, while divorced men will suffer more from a decrease in autonomy and competence. Results indicate that, overall, men and women do not differ as much as is often thought: divorce is negatively related to all dimensions of mental health, for both sexes. Nevertheless, compared to the married, divorced men do report less feelings of competence than their female counterparts, even when controlling for different socio-economic and socialrelational conditions. Although this finding in part contradicts previous findings (Asseltine and Kessler 1993; Horwitz et al. 1996; Marks and Lambert 1998; Shapiro 1996), it is in line with other research indicating a more pronounced disadvantage of divorce for men with regard to happiness and mental health (Marks 1996; Masheter 1991; Mastekaasa 1994; Peters and Liefbroer 1997; Stack and Eshleman 1998; Veenhoven 1984). The fact that this gender difference is found for feelings of competence may result from the fact that most often it are women 
who file for divorce, while men seldom anticipate their demand for divorce (Mortelmans 2008; Wang and Amato 2000). Not being able to keep regular and close contact with children after divorce has an additional detrimental effect (Jacobs 1982; Wang and Amato 2000). Data showed no differences in feelings of depression or selfesteem between divorced women and men.

Third, consistent with previous research, our findings show that the divorced differ significantly from the married on different socio-economic and social-relational conditions: they face more often a risk of poverty, and though the majority of both married and divorced respondents have a close friend and are relatively well integrated into the local community, the married report overall somewhat more of these moderators than the divorced. To a certain extent, these differences can explain the differences in mental health between the married and the divorced because all conditions relate significantly to mental health: a better socio-economic position in terms of employment, education, and income is associated with lower levels of depression and higher levels of self-esteem and competence, and respondents who meet more often with friends, family, and colleagues, have a close friend, and are well integrated into their local community also tend to have overall better mental health. Moreover, the divorced seem to benefit even more than the married from the effects of these conditions on mental health.

Finally, we hypothesised that divorced women are more responsive to socio-economic advantages because the impact of divorce on their socio-economic life is often severe (Amato 2000; Bracke 1998; Holden and Smock 1991). Likewise, we assumed social-relational moderators to be most important for improvements in men's mental health because their emotional support networks are generally smaller and more restricted (Moore 1990). Results showed that only the first assumption could be proved. There does seem to be a gendered aspect, therefore, in how conditions relate to mental health after divorce, although this relationship is not clear cut.

\section{Limitations}

Some limitations should be mentioned. First, the ESS3 is a cross-sectional dataset. Because controlling for initial mental health status is impossible, we cannot make causal interpretations. We should keep in mind the possibility of selectivity, meaning that those who divorced may have done so partially because of lower mental health (cf. supra). Nevertheless, prior research using longitudinal data indicates that divorce causes worse mental health, more than vice versa (Aneshensel 1992).

Second, the ESS3 offers information only with regard to marital status and partner status. No information on relationship- or marital satisfaction was available. Nevertheless, it is likely that this mediates the 
relationship (Hawkins and Booth 2005; Waite et al. 2009). Further research on this topic, using divorcespecialised data, could shed more light on this.

Finally, the fact that the socio-economic and social-relational factors account for only part of the difference in mental health between the continuously married and ever divorced, confirms the results of Bierman et al (2006) and leads us to assume that the link between divorce and mental health is probably also related to the divorce process itself, to individual values concerning marriage and the family, and/or to the quality of relationships.

Nevertheless, this study stresses the multidimensionality of mental health and its relationship to divorce as a major life event for both men and women. Our findings reveal that having experienced a divorce not only relates to feelings of distress, but also inversely to some (but not all) positive indicators of mental health. Moreover, the finding that negative affect and positive affect are only moderately correlated (Bradburn 1969; Huppert and Whittington 2003; Payton 2009) stresses the importance of moving beyond the focus on problems (depression, stress, fear) and problem treatment. Stimulating positive affect (such as feelings of self-esteem and competence) and focussing on possibilities rather than risks is equally important. This study proves that both men and women could benefit when policy and care providers help facilitating the improvement of concrete life conditions (cf. social integration, work, education, etc.), also in order to -partly- overcome the stressful impact of major life changes such as divorce.

\section{References}

Amato, P. R. (2000). The consequences of divorce for adults and children. Journal of Marriage and Family, 62: $1269-1287$.

Amato, P. R., \& Hohmann-Marriott B. (2007). A comparison of high- and low-distress marriages that end in divorce. Journal of Marriage and Family, 69: 621-638.

Aneshensel, C. S. (1992). Social stress: Theory and research. Annual Review of Sociology, 18: 15-38.

Aneshensel, C. S., Rutter, C. M., \& Lachenbruch, P. A. (1991). Social structure, stress, and mental health: Competing conceptual and analytic models. American Sociological Review, 56(2): 166-178.

Aseltine, R. H., \& Kessler, R. C. (1993). Marital disruption and depression in a community sample. Journal of Health and Social Behavior, 34: 237-251.

Barron, C. R. (1987). Women's causal explanations of divorce. Relationship to self-esteem and emotional distress. Research in Nursing and Health, 10(5): 345-353. 
Bierman, A., Fazio, E. M., \& Milkie, M. A. (2006). A multifaceted approach to the mental health advantage of the married: Assesing how explanations vary by outcome measure and unmarried group. Journal of Family Issues, 27(4), 554-582.

Booth, A., \& Amato, P. R. (1991). Divorce and psychological stress. Journal of Health and Social Behavior, 32: 396-407.

Bracke, P. (1993). Geslachtsverschillen in mentale gezondheid. Enkele kritische bedenkingen ontrent het gebruik van het sociale stress model [Gender differences in mental health. Some critical reflections on the use of the social stress model]. Tijdschrift voor Sociologie, 14(2): 223-245.

Bracke, P. (1998). Depressiviteit en de economische gevolgen van echtscheiding voor vrouwen en mannen [Depression and the economic consequences of divorce for women and men]. Mens en Maatschappij, 73(3): 239-258.

Bracke, P. (2000). Over macht en depressiviteit: Een social-relationele visie [On power and depression: A socialrelational perspective]. Tijdschrift voor Sociologie, 21(1): 5-30.

Bracke, P., Colman, E., Symoens, S., \& Van Praag, L. (2010). Divorce, divorce rates, and professional care seeking for mental health problems in Europe: A cross-sectional population-based study. BMC Public Health, 10: 224.

Bradburn, N. M. (1969). The Structure of Psychological Wellbeing. Chicago. IL: Aldine.

Bulloch, A. G., Williams, J. V., Lavorato, D. H., \& Patten, S. B. (2009). The relationship between major depression and marital disruption is bidirectional. Depression and Anxiety, 26: 1172-1177.

Chung, M. C., et al. (2002). Self-esteem, personality and post-traumatic stress symptoms following dissolution of a dating relationship. Stress and Health, 18(2): 83-90.

Cohen, S., Klein, D. N., \& O'Leary, K. D. (2007). The role of separation/divorce in relapse into and recovery from major depression. Journal of Social and Personal Relationships, 24(6): 855-873.

Courtenay, W. H. (2000). Constructions of masculinity and their influence on men's well-being: A theory of gender and health. Social Science and Medicine, 50: 1385-1401.

Doherty, W. J., Su, S., \& Needle, R. (1989). Marital disruption and psychological wellbeing: A panel study. Journal of Family Issues, 10(1): 72-85.

Etaugh, C., \& Foresman, E. (1983). Evaluations of competence as a function of sex and marital status. Sex Roles, 9(7): 759-765. 
Fokkema, T. (2001). Forse inkomensdaling voor vrouwen na echtscheiding en vroege verweduwing: bieden hertrouw en werk uitkomst? [Remarkable decline in income for women after divorce and early widowhood?] Bevolking en Gezin, 30: 5-29.

Gerstel N., Riessman, C. K., \& Rosenfield, S. (1985). Explaining the symptomatology of separated and divorced women and men - The role of material conditions and social networks. Social Forces, 64(1): 84-101.

Greeff, A., \& Van Der Merwe, S. (2004). Variables associated with resilience in divorced families. Social Indicators Research, 68: 59-75.

Hawkins, D. N., \& Booth A. (2005). Unhappily ever after: Effects of long-term, low-quality marriages on wellbeing. Social Forces, 84(1): 445-465.

Holden, K. C., \& Smock, P. J. (1991). The economic costs of marital dissolution - Why do women bear a disproportionate cost? Annual Review of Sociology, 17: 51-78.

Horwitz, A. V. (2002). Outcomes in the sociology of mental health and illness: Where have we been and where are we going? Journal of Health and Social Behavior, 43(2): 143-151.

Horwitz, A. V., White, H. R., \& Howell-White, S. (1996). The use of multiple outcomes in stress research: A case study of gender differences to marital dissolution. Journal of Health and Social Behavior, 37(3): $278-291$.

Huppert, F. A. (2006). Personal and social well-being: Creating indicators for a flourishing Europe. Question module design team (ESS, Round 3) application form. European Social Survey. www.europeansocialsurvey.org/index, accessed 24/09/2008.

Huppert, F. A., \& Whittington, J. E. (2003). Evidence for the independence of positive and negative well-being: Implications for quality of life assessment. British Journal of Health Psychology, 8: 107-122.

Ishida, J. (2003). The role of social norms in a model of marriage and divorce. Journal of Economic Behavior and Organization, 51: 131-142.

Jacobs, J. W. (1982). The effect of divorce on fathers: An overview of the literature. American Journal of Psychiatry, 139(10): 1235-1241.

Johnson D. R., \& Wu, J. (2002). An empirical test of crisis, social selection, and role explanations of the relationship between marital disruption and psychological distress: A pooled time-series analysis of four-wave panel data. Journal of Marriage and Family, 64(1): 211-224. 
Joung, I. M. A., Van de Mheen, H. D., Stronks, K., Van Poppel, F. W. A., \& MacKenbach, J. P. (1998). A longitudinal study of health selection in marital transitions. Social Science and Medicine, 46(3): 425435.

Jowell, R. (with the Central Coordinating Team) (2007). European Social Survey 2006/2007: Technical Report. London: Centre for Comparative Social Surveys, City University 2007, http://www.europeansocialsurvey.com, accessed February, 142007.

Kalmijn, M. (2007). Gender differences in the effects of divorce, widowhood and remarriage on intergenerational support: Does marriage protect fathers? Social Forces, 85(3): 1079-1104.

Kalmijn, M. (2010). Country differences in the effects of divorce on well-being: The role of norms, support, and selectivity. European Sociological Review, 26(4): 475-490.

Kalmijn, M., \& Broese van Groenou, M. I. (2005). Differential effects of divorce on social integration. Journal of Social and Personal Relationships, 22: 455-476.

Kalmijn, M., \& de Graaf, P. M. (2000). Gescheiden vaders en hun kinderen: Een empirische analyse van voogdij en bezoekfrequentie [Divorced fathers and their children: An empirical analysis of custody and visiting frequency]. Bevolking en Gezin, 2: 59-84.

Kalmijn, M., \& Luijkx, R. (2005). Has the reciprocal relationship between employment and marriage changed for men? An analysis of the life histories of men born in the Netherlands between 1930 and 1970. Population Studies, 59(2): 211-231.

Kalmijn, M., \& Monden C. (2006). Are there negative effects of divorce on well-being dependent on marital quality? Journal of Marriage and Family, 68: 1197-1213.

Keyes, C. L. M. (2005). Subjective well-being in mental health and human development research worldwide: An introduction. Social Indicators Research, 77: 1-10.

Keyes, C. L. M., Smothkin, D., \& Ryff, C. D. (2002). Optimizing well-being: The empirical encounter of two traditions. Journal of Personality and Social Psychology, 82(6): 1007-1022.

Kitson, G. C. (1992). Portrait of Divorce: Adjustment to Marital Breakdown. NY: Guilford.

Kitson, G. C., \& Morgan, L. A. (1990). The multiple consequences of divorce: A decade review [Family Research in the 1980s: The Decade in Review]. Journal of Marriage and Family, 52(4): 913-924.

Korenman, S., \& Neumark, D. (1991). Does marriage really make men more productive? Journal of Human Resources, 26(2): 282-307. 
Lee, S., Cho, E, Grodstein, F, Kawachi, I., Hu, F. B., et al. (2005). Effects of marital transitions on changes in dietary and other health behaviors in US women. International Journal of Epidemiology, 34: 69-78.

Liang, W. B., \& Chikritzhs, T. (2012). Brief report: Marital status and alcohol consumption behaviours. Journal of Substance Use, 17(1): 84-90.

Lippman, L. H., Moore K. A., \& McIntosh, H. (2011). Positive indicators of child well-being: A conceptual framework, measures, and methodological issues. Applied Research in Quality of Life, 6(4), 425-449.

Lucas, R. E. (2005). Time does not heal all wounds. A longitudinal study of reaction and adaptation to divorce. Psychological Science, 16(12): 945-950.

Marks, N. F. (1996). Flying solo at midlife: Gender, marital status, and psychological well-being. Journal of Marriage and Family, 58: 917-932.

Marks, N. F., \& Lambert, J. D. (1998). Marital status continuity and change among young and midlife adults. Journal of Family Issues, 19: 652-686.

Masheter, C. (1991). Postdivorce relationships between ex-spouses: The roles of attachment and interpersonal conflict. Journal of Marriage and Family, 53: 103-110.

Matsekaasa, A. (1994). Marital status, distress and well-being: An international comparison. Journal of Comparative Family Studies, 25: 183-206.

Matzger, H., Delucchi, K., Weisner, C., \& Ammon, L. (2004). Does marital status predict long-term drinking? Five-year observations of dependent and independent problem drinkers. Journal of Studies on Alcohol, 65(2): 255-265.

McBride, C., Bacchiochi, J. R., \& Bagby, R. M. (2005). Gender differences in the manifestation of sociotropy and autonomy personality traits. Personality and Individual Differences, 38: 129-136.

Menaghan, E. G. (1985). Depressive Affect and Subsequent Divorce. Journal of Family Issues, 6(3): 295-306.

Moore, G. (1990). Structural determinants of men's and women's personal networks. American Sociological Review, 55: 726-735.

Mortelmans, D. (2008). Copingstrategieën en beleving van sociaal-economische gevolgen bij gescheiden vaders [Coping Strategies and the Experience of Social-economic Consequences in Divorced Fathers]. In D. Cuypers, D. Mortelmans and N. Torfs (Eds.), Is echtscheiding werkelijk win for life? [Is Divorce really Win for life?] (pp. 99-134), Brugge: Die Keure.

Nolen-Hoeksema, S., \& Jackson, B. (2001). Mediators of the gender difference in rumination. Psychology of Women Quarterly, 25: 37-47. 
Divorce and the multidimensionality of men and women's mental health.

Payton, A. R. (2009). Mental health, mental illness, and psychological distress: Same continuum or distinct phenomena? Journal of Health and Social Behavior, 50: 213-27.

Pearlin, L. I. (1989). The sociological study of stress. Journal of Health and Social Behavior, 30(3): 241-256.

Pearlin, L. I., Menaghan, E.G., Lieberman, M. A., \& Mullan, J. T. (1981). The stress process. Journal of Health and Social Behavior, 22(4): 337-356.

Peters, A., \& Liefbroer, A. C. (1997). Beyond marital status: Partner history and well-being in old age. Journal of Marriage and Family, 59(3): 687-699.

Power, C., Rodgers, B., \& Hope S. (1999). Heavy alcohol consumption and marital status: Disentangling the relationship in a national study of young adults. Addiction, 94(10): 1477-1487.

Radloff, L. S. (1977). The CES-D Scale: A self-report depression scale for research in the general population. Applied Psychological Measurement, 1: 385-401.

Rosenberg, M. (1965). Society and the Adolescent Self-image. Princeton: Princeton University Press.

Rosenthal, C. J. (1985). Kinkeeping in the familial division of labor. Journal of Marriage and Family, 47(4): 965-974.

Ross, C. E. (1991). Marriage and the sense of control. Journal of Marriage and Family, 53(4): 831-838.

Ryan, R. M., \& Deci, E. L. (2001). On happiness and human potentials: A review of research on hedonic and eudaimonic well-being. Annual Reviews of Psychology, 52: 141-166.

Ryff, C. D. (1989). Happiness is everything, or is it? Explorations on the meaning of psychological well-being. Journal of Personality and Social Psychology, 57: 1069-1081.

Ryff, C. D., \& Singer, B. (1998). The contours of positive human health. Psychological Inquiry, 9(1): 1-28.

Seff, M. A., Gecas, V., \& Ray, M. P. (1992). Injury and depression: The mediating effects of self-concept. Sociological Perspectives, 35(4): 573-591.

Shapiro, A. (1996). Explaining psychological distress in a sample of remarried and divorced persons. Journal of Family Issues, 17: 186-203.

Simon, R. L., \& Marcussen, K. (1999). Marital transitions, marital beliefs and mental health. Journal of Health and Social Behavior, 40: 111-125.

Simon, R. W. (2002). Revisiting the relationships among gender, marital status, and mental health. American Journal of Sociology, 4: 1065-1096.

Stack, S., \& Eshleman, J. R. (1998). Marital status and happiness: A 17-nation study. Journal of Marriage and Family, 60: 527-536. 
Strohschein, L., McDonough, P., Monette, G., \& Shao, Q. (2005). Marital transitions and mental health: Are there gender differences in the short term effects of marital status change? Social Health and Medicine, 61(11): 2293-2303.

Terhell, E. L., Broese van Groenou, M. I., \& Van Tilburg, T. (2004). Network dynamics in the long-term period after divorce. Journal of Social and Personal Relationships, 21(6): 719-738.

Thoits, P. A. (1994). Stressors and problem solving: The individual as psychological activist. Journal of Health and Social Behavior, 35(2): 143-160.

Turner, R. J., Wheaton, B., \& Lloyd, D. A. (1995). The epidemiology of social stress. American Sociological Review, 60(1): 104-125.

Van de Velde, S., Bracke, P., \& Levecque, K. (2010). Gender differences in depression in 23 European countries. Cross-national variation in the gender gap in depression. Social Science and Medicine 71: $305-313$.

Van de Velde, S., Bracke, P., Levecque, K., \& Meuleman, B. (2010). Gender differences in depression in 25 European countries after eliminating measurement bias in the CES-D 8. Social Science Research, 39(3): 396-404.

Veenhoven, R. (1984). Zonder partner even gelukkig? [Equally happy without a spouse?] in: R. Veenhoven, (red.), Betere wereld, gelukkiger mensen?, Swets \& Zeitlinger, Lisse, pp. 44-60.

Veenhoven, R. (1985). Hoe schadelijk is scheiding? [How harmfull is divorce?] in: C.J. Corver, W. Dumon, \& J.M. Jonker (red.), Primaire Leefvormen, ontwikkelingen in theorieën, onderzoek en problemen in de jaren zestig, SISWO Amsterdam, pp. 149-158.

Veenhoven, R. (1989). Does happiness bind? Marriage chances of the unhappy, in: R. Veenhoven, \& A. Hagenaars (eds.) How harmful is happiness? Consequences of enjoying life or not. Universitaire pers, Rotterdam, pp. 44-60.

Waite, L. J., Luo, Y., \& Lewin, A. C. (2009). Marital happiness and marital stability: Consequences for psychological well-being. Social Science Research, 38: 201-212.

Wang, H., \& Amato, P. R. (2000). Predictors of divorce adjustment: Stressors, resources and definitions. Journal of Marriage and Family, 62: 655-668.

Wheaton, B. (1983). Stress, personal coping resources, and psychiatric symptoms: An investigation of interactive models. Journal of Health and Social Behavior, 24(3): 208-229. 
Divorce and the multidimensionality of men and women's mental health.

Wheaton, B. (1990). Life transitions, role histories, and mental health. American Sociological Review, 55: 209223. 
Table 1.

Descriptives of the sample (ESS3, 2006-2007).

\begin{tabular}{|c|c|c|c|c|c|c|}
\hline & Married & Divorced & & Men & Women & \\
\hline & $\mathrm{M}(\mathrm{SD}) / \%$ & $\mathrm{M}(\mathrm{SD}) / \%$ & p. & $\mathrm{M}(\mathrm{SD}) / \%$ & $\mathrm{M}(\mathrm{SD}) / \%$ & p. \\
\hline \multicolumn{7}{|l|}{ Dependent variables } \\
\hline Depressive feelings (8-32) & $13.45(3.78)$ & $14.58(4.41)$ & $* * *$ & $13.38(3.79)$ & $14.14(4.16)$ & $* * *$ \\
\hline Self-Esteem $(2-10)$ & $7.46(1.48)$ & 7.21(1.61) & $* * *$ & $7.51(1.48)$ & $7.27(1.55)$ & $* * *$ \\
\hline Competence (2-10) & 7.14(1.37) & $7.05(1.47)$ & $* * *$ & $7.14(1.4)$ & 7.04(1.41) & $* * *$ \\
\hline Autonomy (1-5) & $3.91(0.86)$ & $3.93(0.95)$ & & $3.97(0.86)$ & $3.91(0.9)$ & $* * *$ \\
\hline \multicolumn{7}{|l|}{ Marital Status, gender, and age } \\
\hline Divorced & & & & $18.60 \%$ & $21.70 \%$ & $* * *$ \\
\hline Women & $54.50 \%$ & $59.30 \%$ & $* * *$ & & & \\
\hline Age & $45.04(9.31)$ & $46.98(8.35)$ & $* * *$ & $43.37(10.08)$ & 43.64(9.94) & * \\
\hline \multicolumn{7}{|l|}{ Social-relational factors } \\
\hline Children in household & $74.80 \%$ & $56.50 \%$ & $* * *$ & $55.50 \%$ & $65.70 \%$ & $* * *$ \\
\hline Living with a partner & $99.20 \%$ & $50.30 \%$ & $* * *$ & $77.30 \%$ & $77.10 \%$ & \\
\hline Social activities & $4.83(1.54)$ & $4.85(1.59)$ & & $4.96(1.52)$ & $4.89(1.56)$ & $* * *$ \\
\hline Having an intimate friend & $94.00 \%$ & $90.10 \%$ & $* * *$ & $91.70 \%$ & $93.50 \%$ & $* * *$ \\
\hline Local integration & $3.61(0.9)$ & $3.33(0.99)$ & $* * *$ & $3.47(0.94)$ & $3.51(0.95)$ & $* * *$ \\
\hline \multicolumn{7}{|l|}{ Socio-economic factors } \\
\hline Having a job & $72.30 \%$ & $74.40 \%$ & $* *$ & $82.70 \%$ & $64.30 \%$ & $* * *$ \\
\hline Years of full-time education & $12.76(3.82)$ & $13.02(3.69)$ & $* * *$ & $13.13(3.84)$ & $12.9(3.85)$ & $* * *$ \\
\hline$<50 \%$ of median income (Inc1) & $10.10 \%$ & $13.40 \%$ & $* * *$ & $9.90 \%$ & $12.10 \%$ & $* * *$ \\
\hline $50-79 \%$ of median income (Inc2) & $14.50 \%$ & $16.30 \%$ & $* * *$ & $13.20 \%$ & $15.70 \%$ & $* * *$ \\
\hline $80-119 \%$ of median income (Inc3) & $21.60 \%$ & $21.40 \%$ & & $21.20 \%$ & $20.90 \%$ & \\
\hline$>120 \%$ of median income (Inc 4) & $33.80 \%$ & $32.60 \%$ & & $36.90 \%$ & $31.10 \%$ & $* * *$ \\
\hline Income missing (Inc5) & $20.00 \%$ & $16.30 \%$ & $* * *$ & $18.80 \%$ & $20.10 \%$ & $* *$ \\
\hline
\end{tabular}


Table 2.

Multilevel results: Social-relational and socio-economic factors and the mental health of continuously married and ever divorced respondents and (ESS3, 2006-2007).

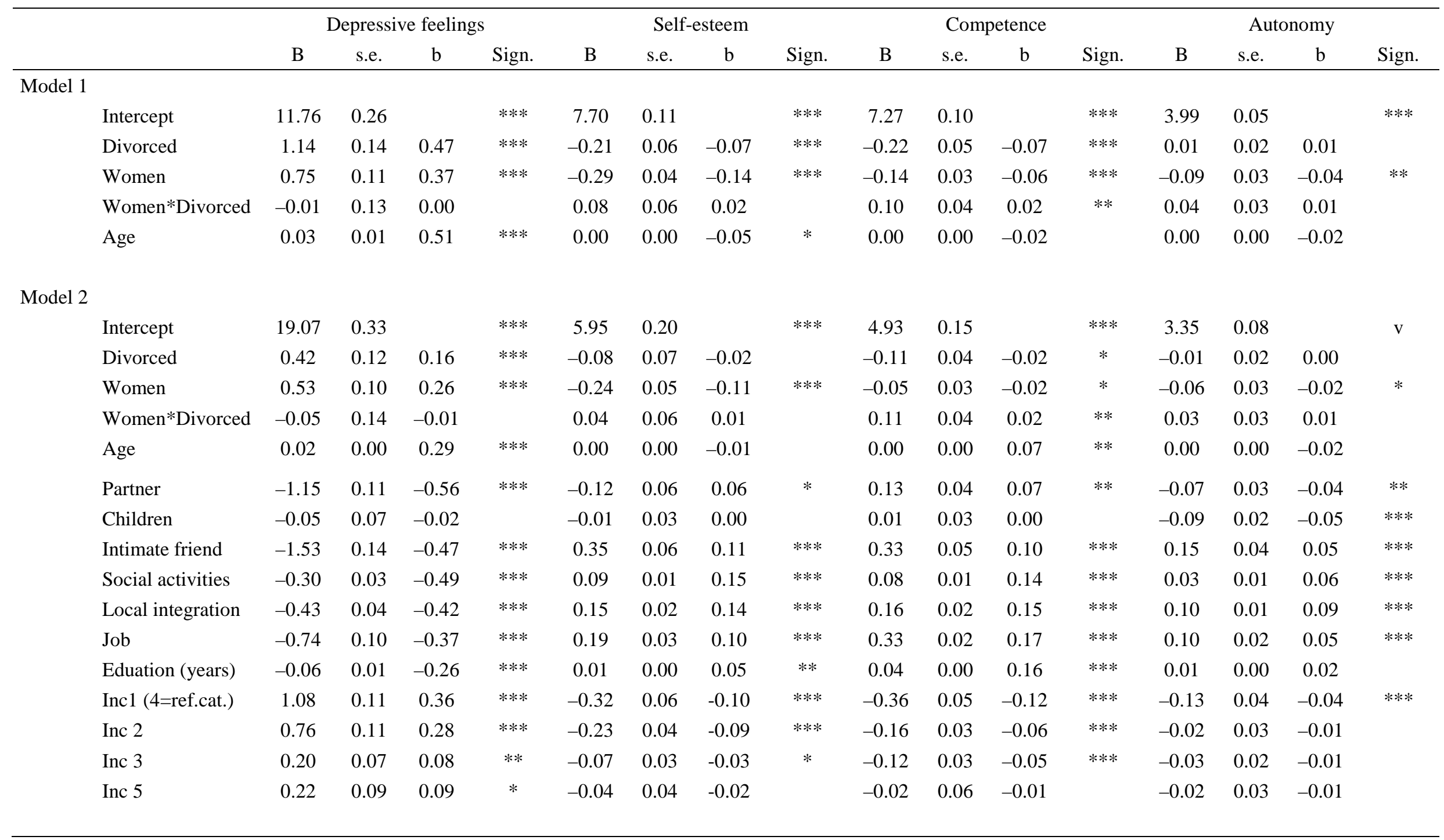


Divorce and the multidimensionality of men and women's mental health. 